medRxiv preprint doi: https://doi.org/10.1101/2021.12.06.21267342; this version posted December 7, 2021. The copyright holder for this preprint (which was not certified by peer review) is the author/funder, who has granted medRxiv a license to display the preprint in

It is made available under a CC-BY 4.0 International license.

\title{
Pharmacokinetics of $B$-d-N4-hydroxycytidine, the active metabolite of prodrug molnupiravir, in non-plasma compartments of patients with SARS-CoV-2 infection.
}

Richard FitzGerald $^{1 *}$, Laura Dickinson ${ }^{2 *}$, Laura Else ${ }^{2}$, Thomas Fletcher ${ }^{3}$, Colin Hale ${ }^{1}$, Alieu Amara $^{2}$, Lauren Walker ${ }^{1}$, Sujan Dilly Penchala ${ }^{2}$, Rebecca Lyon ${ }^{1}$, Victoria Shaw ${ }^{2}$, William Greenhalf ${ }^{2}$, Lara Lavelle-Langham ${ }^{2}$; Helen Reynolds ${ }^{2}$, Wendy Painter ${ }^{4}$, Wayne Holman ${ }^{4}$, Sean Ewings $^{5}$, Gareth Griffiths ${ }^{5}$, Saye Khoo ${ }^{1,2}$

\section{* Contributed equally}

${ }^{1}$ Liverpool University Hospital NHS Foundation Trust, Liverpool, UK; ${ }^{2}$ University of Liverpool, Liverpool, UK; ${ }^{3}$ Liverpool School of Tropical Medicine, Liverpool, UK; 4 Ridgeback Biotherapeutics, Miami, FL, USA; ${ }^{5}$ NIHR Southampton Clinical Trials Unit, University of Southampton, Southampton, UK

\begin{abstract}
Background: Molnupiravir, an orally administered prodrug of the broadly active, direct-acting antiviral, ribonucleoside analogue $\beta-\mathrm{d}-\mathrm{N} 4-$ hydroxycytidine (NHC) is a promising COVID-19 drug candidate. We characterised the pharmacokinetics of NHC in saliva, nasal secretions and tears of patients enrolled in the phase I AGILE trial (NCT04746183) to understand its potential in preventing infection and transmission.
\end{abstract}

Methods: Patients with PCR-confirmed SARS-CoV-2 infection, within 5 days of symptom onset with mild-to-moderate disease were randomised to oral molnupiravir 300, 600 or $800 \mathrm{mg}$ twice daily or placebo. Plasma and non-plasma (saliva, nasal secretions and tears) samples were collected at pre-dose, $0.5,1,2$, and 4 hours post-dose on study days 1 and 5 and molnupiravir and NHC measured by LC/MS with a lower limit of quantification of $2.5 \mathrm{ng} / \mathrm{mL}$ in all matrices. Pharmacokinetic parameters were determined by noncompartmental methods and non-plasma:plasma ratios ( $\mathrm{R}_{\mathrm{NP}: \mathrm{P}}$; based on $\left.\mathrm{AUC}_{0-4}\right)$ calculated.

Results: Twelve participants ( $n=4$ per dosing arm; $75 \%$ female) completed the study. NHC $\mathrm{T}_{\max }$ ranged between 1.00-4.00 hours for saliva $(\mathrm{n}=21)$ and nasal swabs $(\mathrm{n}=22)$ and $0.50-4.00$ hours $(\mathrm{n}=17)$ for tears compared to 1.00-2.00 hours for plasma $(\mathrm{n}=19)$. Median (range) saliva $\mathrm{R}_{\mathrm{NP}: \mathrm{P}}$ pooled across doses was $0.03(0.01-0.11) ; \mathrm{n}=16 . \mathrm{R}_{\mathrm{NP}: \mathrm{P}}$ for nasal secretions and tears were $0.21(0.05-0.73) ; \mathrm{n}=17$ and $0.22(0.09-1.05) ; \mathrm{n}=12$, respectively. Non-plasma and plasma concentrations were significantly correlated $(p<0.0001)$.

Conclusion: These data provide encouraging information regarding the distribution of NHC

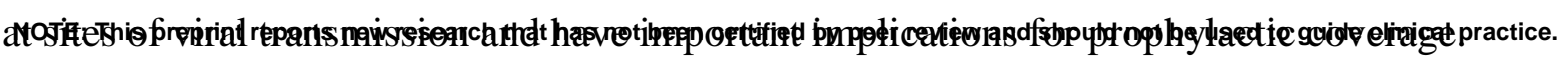


medRxiv preprint doi: https://doi.org/10.1101/2021.12.06.21267342; this version posted December 7, 2021. The copyright holder for this preprint (which was not certified by peer review) is the author/funder, who has granted medRxiv a license to display the preprint in

It is made available under a CC-BY 4.0 International license .

\section{INTRODUCTION}

There is a need for effective antivirals to treat SARS-CoV-2 infection, which if commenced in a timely manner may prevent the development of severe disease. An extended therapeutic goal of antiviral therapy is the prevention of infection in individuals that have been exposed to an infected person. Viral infection occurs through inhalation or inoculation of virus onto upper respiratory airways and mucosal surfaces. In order to be an effective prophylactic agent in such cases, drug must penetrate into sites of inoculation in sufficient quantities.

Molnupiravir (EIDD-2801; MK-4482), a prodrug of the broadly active, direct-acting antiviral, ribonucleoside analogue $14 \beta$-d-N4-hydroxycytidine (NHC), has recently been licensed in the UK for the treatment of symptomatic COVID-19 in adults with at least one risk factor for developing severe disease. Following oral administration, molnupiravir is rapidly hydrolysed by esterases to $\mathrm{NHC}$, which in turn is phosphorylated by host kinases to active metabolite EIDD-1931-5'-triphosphate (EIDD-2061) [1, 2]. AGILE, a UK platform for early-phase trials of novel COVID-19 therapies [3], has evaluated molnupiravir within its AGILE CandidateSpecific Trial (CST)-2 seamless phase Ib/IIa protocol. We previously reported phase $\mathrm{Ib}$ evaluation of molnupiravir across three dosing arms (300, 600 and $800 \mathrm{mg}$ twice daily), establishing that a dose of $800 \mathrm{mg}$ twice daily for 5 days was well-tolerated, achieving plasma concentrations within the target range extrapolated from animal models, and was suitable for progression to phase II [4], which is currently recruiting.

In this study we investigated the pharmacokinetics of molnupiravir and NHC in saliva, nasal secretions and tears, in comparison with concentrations in plasma within the phase $\mathrm{Ib}$ component which we report here. 
medRxiv preprint doi: https://doi.org/10.1101/2021.12.06.21267342; this version posted December 7, 2021. The copyright holder for this preprint (which was not certified by peer review) is the author/funder, who has granted medRxiv a license to display the preprint in

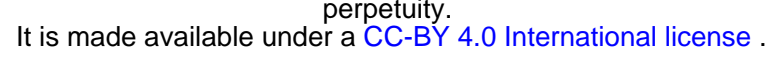

\section{METHODS}

\section{Study Design}

The pharmacokinetics of molnupiravir were evaluated as part of a phase I dose-escalation study in patients with PCR-confirmed SARS-CoV-2 infection, who were within 5 days of symptom onset and presenting with mild or moderate disease (clinicaltrials.gov registration number NCT04746183). The study design has previously been described [4]. In brief, eligible individuals were randomly assigned to one of three sequential dosing cohorts - molnupiravir dosed orally at 300, 600 and $800 \mathrm{mg}$ twice daily. Within each cohort, patients were randomised at a 2:1 allocation ratio to receive either molnupiravir plus standard-of-care (treatment arms; $\mathrm{n}=4$ per cohort) or standard-of-care alone (control arms; $n=2$ per cohort). The study was approved by the UK Medicines and Healthcare product Regulatory Agency (MHRA; EudraCT 2020-001860-27) and West Midlands Edgbaston Research Ethics Committee (20/ WM/0136) and all individuals provided written informed consent. The trial was coordinated by the National Institute for Health Research (NIHR) Southampton Clinical Trials Unit (Southampton UK) with recruitment and treatment of patients taking place at the NIHR Royal Liverpool and Broadgreen Clinical Research Facility (Liverpool, UK).

\section{Pharmacokinetic sampling}

Plasma and non-plasma (saliva, nasal secretions and tears) samples were collected at pre-dose, $0.5,1,2$, and 4 hours post-dose on study days 1 and 5 in order to characterise the single dose and steady-state pharmacokinetics of the molnupiravir and its active metabolite, NHC within these compartments.

Plasma samples were collected as previously described [5]. Saliva samples were collected using Salivette ${ }^{\mathrm{TM}}$ tubes (Sarstedt Ltd, UK). The patient was asked to chew on the Salivette 
medRxiv preprint doi: https://doi.org/10.1101/2021.12.06.21267342; this version posted December 7, 2021. The copyright holder for this preprint (which was not certified by peer review) is the author/funder, who has granted medRxiv a license to display the preprint in

It is made available under a CC-BY 4.0 International license.

swab for approximately 60 seconds after which the swab was returned to the Salivette and centrifuged (within 30 minutes of collection) to yield liquid saliva. The saliva supernatants (50 $\mu \mathrm{L}$ ) were then immediately treated with acetonitrile (acetonitrile:saliva $3: 1 \mathrm{v} / \mathrm{v}$ ) in order to prevent ongoing conversion (via host esterases) of the molnupiravir pro-drug to NHC.

Nasal secretions were collected using 2 x Synthetic Absorptive Matrix (SAM) strips (Mucosal Diagnostics, UK). The applicator was removed from the tube and the absorption end of the swab carefully inserted into the patient's nostril (one each side) with the absorbent strip placed flat against the surface of the inferior turbinate for 60 seconds. The swab was then returned to its original tube and screwed in place using the applicator handle. The weight (to the nearest $0.1 \mathrm{mg}$ ) of each SAM strip was determined before and after sampling in order to ascertain the approximate weight of fluid absorbed.

Tears were collected using 2 x Schirmer Tear Test strips which were inserted under the patient's lower eyelid (one in each eye) for 5 minutes. The approximate volume (to the nearest $\mu \mathrm{L})$ was recorded immediately after collection using the graduated markings on the strip (1-35 $\mu \mathrm{L}$ ) and the strip placed inside a clean labelled $2 \mathrm{~mL}$ polypropylene tube.

All pharmacokinetic specimens were transported and processed on wet ice and stored at $-80^{\circ} \mathrm{C}$ within 60 minutes of collection.

\section{Bioanalytical Methods}

Molnupiravir and NHC concentrations in plasma and saliva were determined at the University of Liverpool Bioanalytical Facility (Liverpool, UK) using a validated LC-MS method, as described previously [5]. Similarly, NHC concentrations in nasal secretions and tears (swab 
medRxiv preprint doi: https://doi.org/10.1101/2021.12.06.21267342; this version posted December 7, 2021. The copyright holder for this preprint (which was not certified by peer review) is the author/funder, who has granted medRxiv a license to display the preprint in

It is made available under a CC-BY 4.0 International license .

samples) were determined using an adaptation of this analytical method. In brief, $2 \mathrm{~mL}$ of acetonitrile: $1 \mathrm{mM}$ ammonium acetate $(50: 50 \mathrm{v} / \mathrm{v})$ was added directly to the tubes containing the swab (calibrators, quality controls and patient samples) and allowed to stand for 1 hour at room temperature. The tubes were sonicated for 30 minutes and exactly $1.8 \mathrm{~mL}$ transferred to clean labelled $5 \mathrm{~mL}$ glass tubes containing $20 \mu \mathrm{L}$ of working internal standard solution $(2.5 \mu \mathrm{g} / \mathrm{mL}$ ${ }^{13} \mathrm{C}_{15} \mathrm{~N}_{2}$-N4-hydroxycytidine). Samples were then vortexed, evaporated to dryness under nitrogen at ambient temperature and reconstituted with $200 \mu \mathrm{L}$ of $1 \mathrm{mM}$ ammonium acetate (adjusted to $\mathrm{pH} 4.3$ ) ready for injection onto the LC-MS system. Standards and quality controls were freshly prepared on the day of analysis. Working solutions were prepared in $1 \mathrm{x}$ phosphate-buffered saline (PBS) fresh (which served as a surrogate matrix) and $15 \mu \mathrm{L}$ of each calibrator level pipetted onto a clean SAM or tear strip (in duplicate). The calibration curve ranged between $0.15-75 \mathrm{ng} / \mathrm{sample}$, and was described using a weighted $\left(1 / \mathrm{x}^{2}\right)$ least square linear regression model.

\section{Pharmacokinetic Data Analysis}

Concentrations of NHC in plasma and saliva were measured in $\mathrm{ng} / \mathrm{mL}$, whereas nasal and tear swab NHC were quantified using a ng/sample calibration curve, and converted to $\mathrm{ng} / \mathrm{mL}$ based on swab volume in $\mu \mathrm{L}$.

Following administration of 300, 600 and $800 \mathrm{mg}$ doses of molnupiravir, NHC concentrations on study day 1 and 5 in each sampling matrix, at each nominal time point [pre-dose (0), 0.5, 1 , 2, 4 hours post-dose] were described using summary statistics such as geometric mean $(90 \%$ CI), mean, standard deviation, median and range. Samples below the lower limit of quantification of the assay (LLQ; $<2.5 \mathrm{ng} / \mathrm{mL}$ ) at pre-dose on day 1 were included as $0 \mathrm{ng} / \mathrm{mL}$, whereas those <LLQ beyond pre-dose on day 1 were included as LLQ/2 $(1.25 \mathrm{ng} / \mathrm{mL})$. 
medRxiv preprint doi: https://doi.org/10.1101/2021.12.06.21267342; this version posted December 7, 2021. The copyright holder for this preprint (which was not certified by peer review) is the author/funder, who has granted medRxiv a license to display the preprint in

It is made available under a CC-BY 4.0 International license .

NHC pharmacokinetic parameters, area under the concentration-time curve $0-4$ hours $\left(\mathrm{AUC}_{0}\right.$ 4), maximum concentration $\left(\mathrm{C}_{\max }\right)$ and time to maximum concentration $\left(\mathrm{T}_{\max }\right)$ were determined using non-compartmental modelling methods (Phoenix 64, WinNonlin, v. 8.3, Certara, Princeton, NJ, USA). NHC accumulation ratio $\left(\mathrm{R}_{\mathrm{AC}}\right)$ in non-plasma samples from day 1 to 5 were determined for each molnupiravir dose (Day $5 \mathrm{AUC}_{0-4} / \mathrm{Day}^{1} \mathrm{AUC}_{0-4}$ ). Intercompartmental ratios of non-plasma to plasma $\left(\mathrm{R}_{\mathrm{NP}: \mathrm{P}}\right)$ were calculated on day 1 and 5 for each dose using the plasma compartment as reference (non-plasma $\mathrm{AUC}_{0-4} /$ plasma $\mathrm{AUC}_{0-4}$ ). Results were expressed as geometric mean (CV\%). Patients without a full pharmacokinetic profile between 0-4 hours were excluded from the summary statistics for $\mathrm{AUC}_{0-4}$, and those with sample(s) missing between 0-2 hours were excluded from $\mathrm{C}_{\max }$ and $\mathrm{T}_{\max }$ summary statistics.

Linear regression was performed to evaluate the relationship between NHC concentrations in plasma and non-plasma compartments. Concentrations below assay LLQ were excluded. Data were $\log$ transformed and analysed using IBM SPSS Statistics (v. 25.0, IBM Corporation, Armonk, NY, USA).

\section{RESULTS}

\section{Patients}

Of the twelve participants ( $\mathrm{n}=4$ per dosing arm) with pharmacokinetic data, $9 / 12(75 \%)$ were female, median (range) baseline age, weight and BMI were 50 years (22-80), $79 \mathrm{~kg}$ (54-134) and $29 \mathrm{~kg} / \mathrm{m}^{2}(21-51)$ and time from onset of symptoms to randomisation and start of treatment was 5 days (3-5). 
medRxiv preprint doi: https://doi.org/10.1101/2021.12.06.21267342; this version posted December 7, 2021. The copyright holder for this preprint (which was not certified by peer review) is the author/funder, who has granted medRxiv a license to display the preprint in

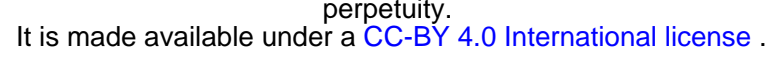

Ten of the twelve individuals $(83 \%)$ completed the full treatment schedule. One patient in the $300 \mathrm{mg}$ cohort took only 1 of 2 tablets for the second and third dose and a participant in the $800 \mathrm{mg}$ cohort withdrew after the second dose; however, collected pharmacokinetic data were included.

\section{Non-plasma samples}

Of note, prodrug molnupiravir was detected at very low concentrations in only 31/106 (29\%) plasma and 12/114 (11\%) saliva samples [median (range) $5.89(2.59-27.53 \mathrm{ng} / \mathrm{mL})$ and 4.86 (2.63-31.44 $\mathrm{ng} / \mathrm{mL}$, respectively] and therefore not measured in swab samples.

In total, 111/114 saliva samples, 112/112 nasal swabs and 97/106 tear test strip concentrations were included. Three saliva samples were excluded due to an incorrect volume of acetonitrile added during processing and $n=10$ tear samples did not have a recorded volume for conversion to $\mathrm{ng} / \mathrm{mL}$. All pre-dose concentrations on day 1 ( $\mathrm{n}=12$ per matrix) were $<\mathrm{LLQ}$, as were three 0.5 hour and one 1 hour saliva sample and $n=1$ tear test strip sample at 0.5 hour post-dose. Additionally, seven pre-dose saliva samples, three nasal swab ( $\mathrm{n}=1$ at 0,2 and 4 hours postdose) and tear strip concentrations ( $\mathrm{n}=2$ at 0 hours, $\mathrm{n}=1$ at 4 hours) on day 5 were below LLQ.

\section{NHC non-plasma pharmacokinetics}

NHC pharmacokinetic parameters are summarised (Table 1). Geometric mean concentrationtime profiles per dosing cohort, stratified by study day are shown (Figure 1) and individual profiles illustrated in the supplementary material (Supplementary Figure 1). 
medRxiv preprint doi: https://doi.org/10.1101/2021.12.06.21267342; this version posted December 7, 2021. The copyright holder for this preprint (which was not certified by peer review) is the author/funder, who has granted medRxiv a license to display the preprint in It is made available under a CC-BY 4.0 International license .

NHC $\mathrm{T}_{\max }$ ranged between 1.00-4.00 hours for saliva $(\mathrm{n}=21)$ and nasal swabs $(\mathrm{n}=22)$ and 0.50 4.00 hours $(\mathrm{n}=17)$ for tears compared to 1.00-2.00 hours for plasma $(\mathrm{n}=19)$. Nasal and tear NHC $R_{A C}$ from single dose to day 5 was below unity for $8 / 9$ and $5 / 6$ patients, respectively. $R_{A C}$ was variable for saliva, but appeared not to accumulate for the $800 \mathrm{mg}$ dose (Table 1). NHC saliva concentrations were approximately $3 \%$ that of plasma [median (range) $\mathrm{R}_{\mathrm{NP}: \mathrm{P}}$ pooled across doses: 0.03 (0.01-0.11); $\mathrm{n}=16]$; the majority of individual ratios were between $0.01-0.04$ $(\mathrm{n}=12)$. Individual patient NHC $\mathrm{R}_{\mathrm{NP}: P}$ for nasal secretions and tears were more variable, particularly for tears (CV\%: 60, 70 and 92\% for saliva, nasal and tears $\mathrm{R}_{\mathrm{NP} P \mathrm{P} .}$ respectively) and overall approximately 6-fold higher than saliva $\mathrm{R}_{\mathrm{NP}: \mathrm{P}}$ [median (range) $\mathrm{R}_{\mathrm{NP}: \mathrm{P}}$ nasal: 0.21 (0.050.73); $\mathrm{n}=17$, tears: $0.22(0.09-1.05) ; \mathrm{n}=12]$. Geometric mean (CV\%) NHC R $\mathrm{R}_{\mathrm{NP}: P}$, stratified by molnupiravir dose and study day are described (Table 1).

\section{Correlation between plasma and non-plasma compartments}

NHC concentrations in saliva and nasal secretions were significantly associated with paired plasma concentrations on day 1 and day 5 ( $p<0.0001$ for all linear regression analyses) with similar correlation coefficient values between study days (Figure 2), whereas a statistically significant relationship was observed for paired tear and plasma NHC concentrations on day 5 $\left(\mathrm{r}^{2}=0.360, p<0.0001\right)$ but not day $1\left(\mathrm{r}^{2}=0.028, p=0.314 ;\right.$ Figure 2$)$. 
medRxiv preprint doi: https://doi.org/10.1101/2021.12.06.21267342; this version posted December 7, 2021. The copyright holder for this preprint (which was not certified by peer review) is the author/funder, who has granted medRxiv a license to display the preprint in

perpetuity.
It is made available under a CC-BY 4.0 International license .

\section{DISCUSSION}

SARS-CoV-2 is primarily transmitted through viral particles contained in droplets and aerosols expelled through the mouth and nose [6]; it is therefore important to also understand drug pharmacokinetics at the sites of initial viral exposure such as the throat, nose and eye. Molnupiravir is the first orally direct-acting antiviral agent licensed for early treatment of mildto-moderate COVID-19 disease in adults with at least one risk factor for developing severe disease. Molnupiravir is currently under phase II evaluation within AGILE including mild-tomoderate COVID-19 without risk factors and in both unvaccinated and vaccinated patients. Furthermore, molnupiravir is also being investigated for prophylactic use in household contacts of symptomatic COVID-19 patients (MOVe-AHEAD; NCT04939428). Knowledge of drug accumulation within the upper airways and in mucosal secretions will inform and support future research in this area.

We observed concentrations of NHC in saliva that were $3 \%$ that of plasma, whereas exposure in nasal secretions and tears was higher at approximately $20 \%$ that of plasma (based on $\mathrm{AUC}_{0}$ 4 ratios). Of the measured saliva, nasal and tear samples, 6, 50 and $61 \%$, respectively were within or above the $\mathrm{NHC} \mathrm{EC}_{90}$ against SARS-CoV-2 in primary human airway epithelia cultures [7, 8] (approximately 0.5-1 $\mu \mathrm{M} \approx 130-260 \mathrm{ng} / \mathrm{mL}$ ), suggesting therapeutic concentrations are potentially attained within the nasal and ocular compartments, but not in saliva. However, it is important to note that without established pharmacokinetic/pharmacodynamic relationships or virological data further studies are warranted to determine whether efficacious targets, or indeed prophylactic targets, are obtained in non-plasma compartments. 
medRxiv preprint doi: https://doi.org/10.1101/2021.12.06.21267342; this version posted December 7, 2021. The copyright holder for this preprint (which was not certified by peer review) is the author/funder, who has granted medRxiv a license to display the preprint in

It is made available under a CC-BY 4.0 International license .

A strong correlation between saliva and plasma NHC concentrations implies (assuming a one compartment model) that salivary accumulation is dependent on the plasma drug concentration. Mucosal permeability and protein binding are major factors in determining salivary drug accumulation, since only unbound drug is available for diffusion into saliva [9]. Of note, NHC exists predominantly in unbound form in plasma (unbound fraction $\geq 0.99$ ) (personal communication, Ridgeback Biotherapeutics) and in vitro studies demonstrated that molnupiravir and NHC are not substrates for efflux transporters ABCB1 (p-glycoprotein), ABCC2 (multidrug resistance-associated protein 2; MRP2) or ABCG2 (breast cancer resistance protein, BCRP; personal communication, Ridgeback Biotherapeutics), suggesting salivary excretion of NHC is potentially modulated by other factors relating to the characteristics of the drug or surrounding milieu. Passage of drugs into non-plasma compartments not only depends on physiochemical properties, protein binding or molecule size, it can also be attributed to factors such as $\mathrm{pH}$ (e.g. mouth), inflammation (e.g. eye) and flow rate. For example, pharmacokinetics of drug in tears may be affected due to increased lacrimation or infection. Higher turnover or flow rate of saliva, compared to nasal secretions and tears may also contribute to the lower concentrations observed. Additionally, the marked variability in nasal and tear NHC concentrations could be related to the challenging collection procedures, particularly for tears, and the accuracy of swab volume for conversion from $\mathrm{ng} / \mathrm{sample}$ to $\mathrm{ng} / \mathrm{mL}$.

Following 5 days of dosing, NHC did not to accumulate in plasma [4] or non-plasma compartments. Accumulation is associated with the elimination rate of drug in relation to the dosing interval. Although we could not determine the elimination rate constant or half-life of NHC (due to truncated sampling) a value of 7 hours has been reported in the literature $(n=4$ healthy volunteers, $800 \mathrm{mg}$ twice daily) [10], and in the absence of enzyme induction or 
medRxiv preprint doi: https://doi.org/10.1101/2021.12.06.21267342; this version posted December 7, 2021. The copyright holder for this preprint (which was not certified by peer review) is the author/funder, who has granted medRxiv a license to display the preprint in It is made available under a CC-BY 4.0 International license .

inhibition, suggests that NHC would not accumulate. Low accumulation in non-plasma compartments could indicate that elimination is dependent upon that of the plasma.

NHC appeared to exhibit a similar absorption and elimination profile in the matrices studied, confirmed by statistically significant linear relationships between NHC in plasma with that in non-plasma compartments (with the exception of tears on day 1). The strong correlation in pharmacokinetics between saliva and plasma suggests the former may be utilised as noninvasive sampling in support of clinical studies.

There are a number of limitations. We utilised a sampling schedule for a truncated pharmacokinetic profile (0-4 hours) to limit infection risk. Missing samples led to a number of exclusions from the analysis, particularly for evaluation of $\mathrm{R}_{\mathrm{NP}: \mathrm{P}}$, contributed to data variability and limited data interpretation. Finally, the active triphosphate metabolite, EIDD-2061 was not quantified. Despite the limitations these data add to our understanding of NHC pharmacokinetics, principally at sites of COVID-19 infection.

To our knowledge this is the first report describing significant accumulation of NHC in nasal secretions and tears, and to a lesser extent saliva. These data support the evaluation of molnupiravir as prophylaxis for SARS-CoV-2 infection. 
medRxiv preprint doi: https://doi.org/10.1101/2021.12.06.21267342; this version posted December 7, 2021. The copyright holder for this preprint (which was not certified by peer review) is the author/funder, who has granted medRxiv a license to display the preprint in

perpetuity.
It is made available under a CC-BY 4.0 International license .

\section{FUNDING}

This work was funded by the University of Liverpool. The AGILE platform infrastructure is supported by the Medical Research Council (grant number MR/V028391/1) and the Wellcome Trust (grant number 221590/Z/20/Z). AGILE CST-2 molnupiravir trial was supported by Ridgeback Biotherapeutics. We acknowledge National Institute for Health Research (NIHR) infrastructure funding for the Liverpool Clinical Research Facility and the Southampton Clinical Trials Unit.

\section{ACKNOWLEDGEMENTS}

The authors wish to thank the patients that participated in the AGILE CST-2 molnupiravir trial and all the staff involved at the NIHR Royal Liverpool and Broadgreen Clinical Research Facility and the Liverpool Bioanalytical Facility. We are grateful to the team at the Southampton Clinical Trials Unit who were involved in study coordination, including Nichola Downs, Geoffrey Saunders, Andrea Corkhill, Kerensa Thorne, Lucy Johnson, Sata Yeats, Kim Mallard, Mike Radford and Keira Fines.

\section{CONFLICT OF INTEREST}

SK has received research funding from ViiV Healthcare, Gilead Sciences, and Merck for the Liverpool HIV Drug Interactions programme and for clinical studies unrelated to the submitted work.

GG has received funding from Jannsen-Cilag, Novartis, Astex, Roche, Heartflow, Bristol Myers Squibb, BioNtech; grants and personal fees from AstraZeneca; and personal fees from Celldex, unrelated to the submitted work.

WG has received funding from the Wellcome Trust.

WH is a cofounder, owner and advisor of/to Ridgeback Biotherapeutics. 
medRxiv preprint doi: https://doi.org/10.1101/2021.12.06.21267342; this version posted December 7, 2021. The copyright holder for this preprint (which was not certified by peer review) is the author/funder, who has granted medRxiv a license to display the preprint in

It is made available under a CC-BY 4.0 International license .

WP is employed by Ridgeback Biotherapeutics.

All other authors have none to declare. 
medRxiv preprint doi: https://doi.org/10.1101/2021.12.06.21267342; this version posted December 7, 2021. The copyright holder for this preprint (which was not certified by peer review) is the author/funder, who has granted medRxiv a license to display the preprint in

perpetuity.
It is made available under a CC-BY 4.0 International license .

\section{REFERENCES}

1. Hernandez-Santiago BI, Beltran T, Stuyver L, Chu CK, Schinazi RF. Metabolism of the anti-hepatitis $\mathrm{C}$ virus nucleoside beta-D-N4-hydroxycytidine in different liver cells. Antimicrob Agents Chemother 2004; 48: 4636-42.

2. Painter GR, Bowen RA, Bluemling GR, et al. The prophylactic and therapeutic activity of a broadly active ribonucleoside analog in a murine model of intranasal venezuelan equine encephalitis virus infection. Antiviral Res 2019; 171: 104597.

3. Griffiths G, Fitzgerald R, Jaki T, et al. AGILE: a seamless phase I/IIa platform for the rapid evaluation of candidates for COVID-19 treatment: an update to the structured summary of a study protocol for a randomised platform trial letter. Trials 2021; 22: 487. doi: 10.1186/s13063-021-05458-4.

4. Khoo SH, Fitzgerald R, Fletcher T, et al. Optimal dose and safety of molnupiravir in patients with early SARS-CoV-2: a Phase I, open-label, dose-escalating, randomized controlled study. J Antimicrob Chemother 2021; 76: 3286-95.

5. Amara A, Penchala SD, Else L, et al. The development and validation of a novel LCMS/MS method for the simultaneous quantification of Molnupiravir and its metabolite ssd-N4-hydroxycytidine in human plasma and saliva. J Pharm Biomed Anal 2021; 206: 114356.

6. Patel KP, Vunnam SR, Patel PA, et al. Transmission of SARS-CoV-2: an update of current literature. Eur J Clin Microbiol Infect Dis 2020; 39: 2005-11.

7. Cox RM, Wolf JD, Plemper RK. Therapeutically administered ribonucleoside analogue MK-4482/EIDD-2801 blocks SARS-CoV-2 transmission in ferrets. Nat Microbiol 2021; 6: 11-8. 
medRxiv preprint doi: https://doi.org/10.1101/2021.12.06.21267342; this version posted December 7, 2021. The copyright holder for this preprint (which was not certified by peer review) is the author/funder, who has granted medRxiv a license to display the preprint in It is made available under a CC-BY 4.0 International license.

8. Sheahan TP, Sims AC, Zhou S, et al. An orally bioavailable broad-spectrum antiviral inhibits SARS-CoV-2 in human airway epithelial cell cultures and multiple coronaviruses in mice. Sci Transl Med 2020; 12.

9. Haeckel R. Factors influencing the saliva/plasma ratio of drugs. Ann N Y Acad Sci 1993; 694: 128-42.

10. Painter WP, Holman W, Bush JA, et al. Human Safety, Tolerability, and Pharmacokinetics of Molnupiravir, a Novel Broad-Spectrum Oral Antiviral Agent with Activity Against SARS-CoV-2. Antimicrob Agents Chemother 2021; 65: e02428-20. 
Table 1 Geometric mean (CV\%) NHC pharmacokinetic parameters from plasma, saliva, nasal swabs and tear strips of SARS-CoV-2 infected patients following single (Day 1) and multiple dose (Day 5) molnupiravir $300 \mathrm{mg}$, $600 \mathrm{mg}$ and $800 \mathrm{mg}$ twice daily (n=4 per dosing arm unless stated otherwise).

\begin{tabular}{|c|c|c|c|c|c|c|}
\hline \multirow[b]{2}{*}{ Parameter } & \multicolumn{2}{|c|}{$300 \mathrm{mg}$} & \multicolumn{2}{|c|}{$600 \mathrm{mg}$} & \multicolumn{2}{|c|}{$800 \mathrm{mg}$} \\
\hline & Day 1 & Day 5 & Day 1 & Day 5 & Day 1 & Day 5 \\
\hline \multicolumn{7}{|l|}{ Plasma } \\
\hline $\mathrm{AUC}_{0-4}(\mathrm{ng} . \mathrm{h} / \mathrm{mL})$ & $3031(45)^{\#}$ & $2328^{\S}$ & $5690(22)^{*}$ & $4368(41)$ & $8187(30)$ & $7005(21)^{*}$ \\
\hline $\mathrm{C}_{\max }(\mathrm{ng} / \mathrm{mL})$ & $1488(31)^{*}$ & $1048(17)^{\#}$ & $2440(17)$ & $1865(61)$ & $3447(32)$ & $3546(13)^{*}$ \\
\hline $\mathrm{T}_{\max }(\mathrm{h})$ & $2.00(1.00-2.00)^{*}$ & $1.00(1.00-1.00)^{\#}$ & $1.00(1.00-2.00)$ & $1.00(1.00-2.00)$ & $2.00(2.00-2.00)$ & $2.00(2.00-2.00)^{\#}$ \\
\hline $\mathrm{R}_{\mathrm{AC}}$ & NA & $\mathrm{NC}$ & NA & $0.91(7)^{*}$ & NA & $0.93(20)^{*}$ \\
\hline \multicolumn{7}{|l|}{ Saliva } \\
\hline $\mathrm{AUC}_{0-4}(\mathrm{ng} \cdot \mathrm{h} / \mathrm{mL})$ & $65(109)^{*}$ & $106(93)^{*}$ & $143(120)$ & $106(77)^{*}$ & $289(52)$ & $237(36)^{*}$ \\
\hline $\mathrm{C}_{\max }(\mathrm{ng} / \mathrm{mL})$ & $29(113)^{*}$ & $41(98)$ & 73 (127) & $48(76)^{*}$ & $134(48)$ & $109(27)^{*}$ \\
\hline $\mathrm{T}_{\max }(\mathrm{h})$ & $1.00(1.00-2.00)^{*}$ & $1.50(1.00-2.00)$ & $2.00(1.00-2.00)$ & $2.00(2.00-4.00)^{*}$ & $2.00(1.00-2.00)$ & $2.00(2.00-2.00)^{*}$ \\
\hline $\mathrm{R}_{\mathrm{AC}}$ & NA & $1.62(31)^{*}$ & NA & $0.59(58)^{*}$ & NA & $1.00(13)^{*}$ \\
\hline $\mathrm{R}_{\mathrm{NP}: \mathrm{P}}$ & $0.03(62)^{\#}$ & $0.03^{\S}$ & $0.04(79)^{*}$ & $0.03(51)^{*}$ & $0.04(33)$ & $0.03(18)^{*}$ \\
\hline \multicolumn{7}{|l|}{ Nasal Swabs } \\
\hline $\mathrm{AUC}_{0-4}(\mathrm{ng} \cdot \mathrm{h} / \mathrm{mL})$ & $1061(38)^{*}$ & $673(27)^{*}$ & $629(64)$ & $716(67)$ & $2164(50)$ & $1611(73)^{*}$ \\
\hline $\mathrm{C}_{\max }(\mathrm{ng} / \mathrm{mL})$ & $805(70)^{*}$ & $484(60)$ & $365(75)$ & $321(65)$ & $1076(43)$ & $738(87)^{*}$ \\
\hline
\end{tabular}




\begin{tabular}{l|c|c|c|c|c|c}
$\mathrm{T}_{\max }(\mathrm{h})$ & $1.00(1.00-1.00)^{*}$ & $1.00(1.00-2.00)$ & $1.00(1.00-2.00)$ & $1.00(1.00-4.00)$ & $1.50(1.00-2.00)$ & $2.00(2.00-4.00)^{*}$ \\
$\mathrm{R}_{\mathrm{AC}}$ & $\mathrm{NA}$ & $0.63(39)^{*}$ & $\mathrm{NA}$ & $0.58(47)^{*}$ & $\mathrm{NA}$ & $0.90(30)^{*}$ \\
$\mathrm{R}_{\mathrm{NP}: \mathrm{P}}$ & $0.41(73)^{\#}$ & $0.23^{\S}$ & $0.17(27)^{*}$ & $0.17(112)$ & $0.26(26)$ & $0.23(67)^{*}$ \\
\hline Tear Strips & & & & & \\
$\mathrm{AUC}_{0-4}(\mathrm{ng} . \mathrm{h} / \mathrm{mL})$ & $1731(44)^{*}$ & $1071(38)^{*}$ & $1137(96)^{*}$ & $749(50)^{\#}$ & $1934(90)^{*}$ & $722^{\S}$ \\
$\mathrm{C}_{\max }(\mathrm{ng} / \mathrm{mL})$ & $908(58)^{*}$ & $674(53)^{*}$ & $411(100)^{*}$ & $508(84)$ & $985(95)^{*}$ & $1267(40)^{*}$ \\
$\mathrm{~T}_{\max }(\mathrm{h})$ & $0.50(0.50-2.00)^{*}$ & $1.00(0.50-2.00)^{*}$ & $2.00(0.50-4.00)^{*}$ & $1.50(1.00-2.00)^{\#}$ & $1.00(1.00-1.00)^{*}$ & $1.00(0.50-1.00)^{*}$ \\
$\mathrm{R}_{\mathrm{AC}}$ & $\mathrm{NA}$ & $0.62(43)^{*}$ & $\mathrm{NA}$ & $1.12(85)^{\#}$ & $\mathrm{NA}$ & $0.80^{\S}$ \\
$\mathrm{R}_{\mathrm{NP}: \mathrm{P}}$ & $0.77(36)^{\#}$ & $0.39^{\S}$ & $0.20(76)^{*}$ & $0.17(47)^{\#}$ & $0.26(121)^{*}$ & $0.10^{\S}$ \\
\hline
\end{tabular}

$\mathrm{T}_{\max }$ expressed as median (range)

${ }^{*} \mathrm{n}=3,{ }^{\#} \mathrm{n}=2,{ }^{\S} \mathrm{n}=1$

NA: not applicable; NC: not calculated due to missing samples on Day 1 or 5 preventing calculation of AUC A-4 $_{4}$ AUC A-4: $_{\text {: }}$ area under the concentration-time curve over 0 hours (pre-dose) to 4 hours post-dose; $\mathrm{C}_{\max }$ : maximum concentration; $\mathrm{T}_{\max }$ : time of maximum concentration; $\mathrm{R}_{\mathrm{AC}}$ : accumulation ratio from day 1 to day 5 (Day 5 AUC $\mathrm{C}_{0-4} / \mathrm{Day} 1 \mathrm{AUC} \mathrm{C}_{0-}$ 4); $\mathrm{R}_{\mathrm{NP}: \mathrm{P}}$ : intercompartmental ratio of non-plasma to plasma (non-plasma $\mathrm{AUC}_{0-4} /$ plasma $\mathrm{AUC}_{0-4}$ ) 
medRxiv preprint doi: https://doi.org/10.1101/2021.12.06.21267342; this version posted December 7, 2021. The copyright holder for this preprint (which was not certified by peer review) is the author/funder, who has granted medRxiv a license to display the preprint in It is made available under a CC-BY 4.0 International license.

\section{FIGURE LEGENDS}

Figure 1 Geometric mean NHC concentrations over time from saliva (closed points, solid line), nasal swabs (open points, solid line) and tear strips (closed points, broken line) of individuals with SARS-CoV-2 following (A) single dose (Day 1) and (B) multiple dose (Day 5) molnupiravir $300 \mathrm{mg}$ (circles), $600 \mathrm{mg}$ (squares) and $800 \mathrm{mg}$ (diamonds) twice daily. Data are expressed on a log-linear scale.

Figure 2 Matched NHC concentrations from (A) saliva, (B) nasal swabs and (C) tear strips versus plasma concentrations following single dose (Day 1; left pane) and multiple dose (Day 5; right pane) molnupiravir $300 \mathrm{mg}, 600 \mathrm{mg}$ and $800 \mathrm{mg}$ twice daily. Concentrations at each dose were pooled, $\log 10$ transformed and analysed using linear regression; $p \leq 0.05$ was considered statistically significant. 
medRxiv preprint doi: https://doi.org/10.1101/2021.12.06.21267342; this version posted December 7, 2021. The copyright holder for this preprint (which was not certified by peer review) is the author/funder, who has granted medRxiv a license to display the preprint in

It is made available under a CC-BY 4.0 International license .

\section{Figure 1}

(A)

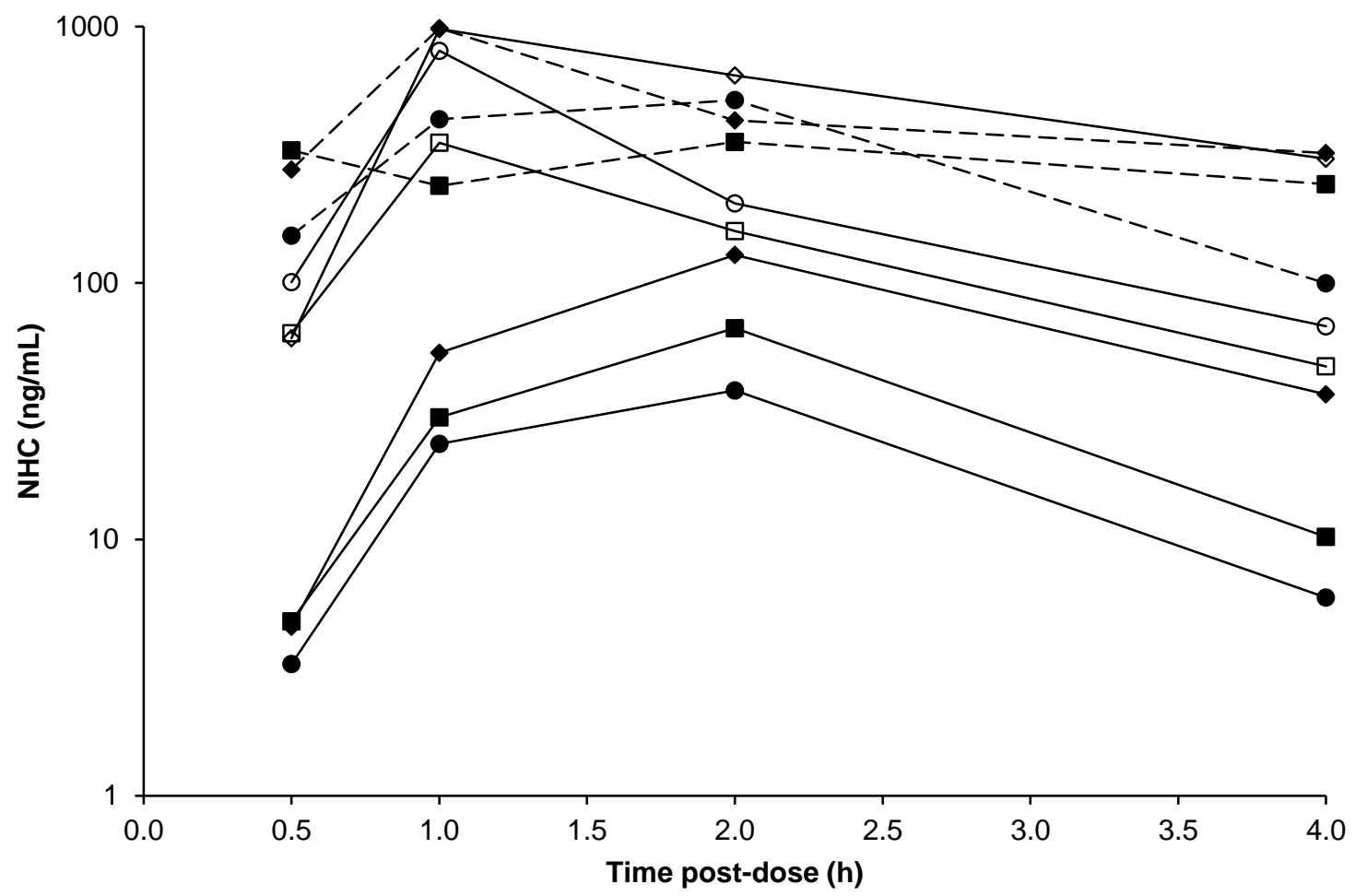

(B)

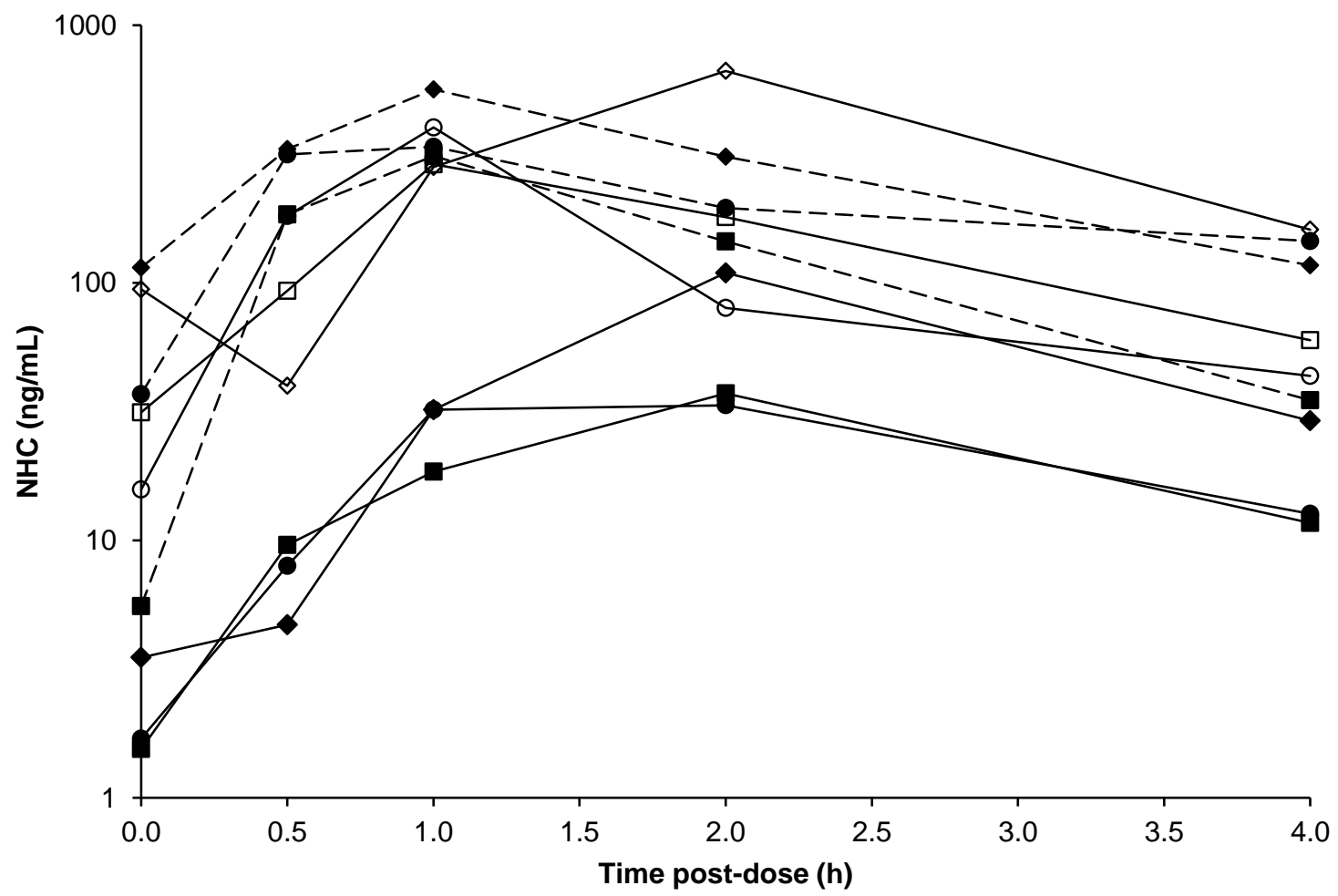

$\longrightarrow$ - Molnupiravir 300 mg; saliva ——Molnupiravir 600 mg; saliva $\longrightarrow$ Molnupiravir 800 mg; saliva

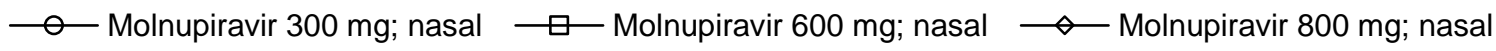

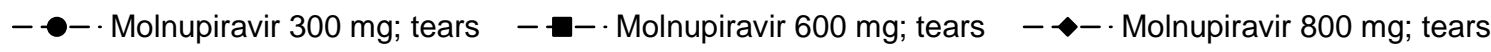


medRxiv preprint doi: https://doi.org/10.1101/2021.12.06.21267342; this version posted December 7, 2021. The copyright holder for this preprint (which was not certified by peer review) is the author/funder, who has granted medRxiv a license to display the preprint in perpetuity.

It is made available under a CC-BY 4.0 International license .

\section{Figure 2}

(A)

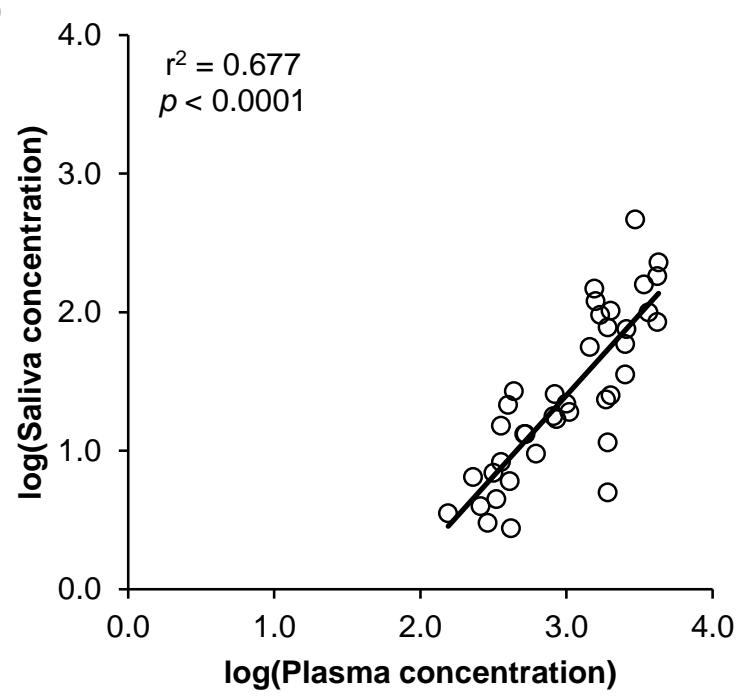

(B)

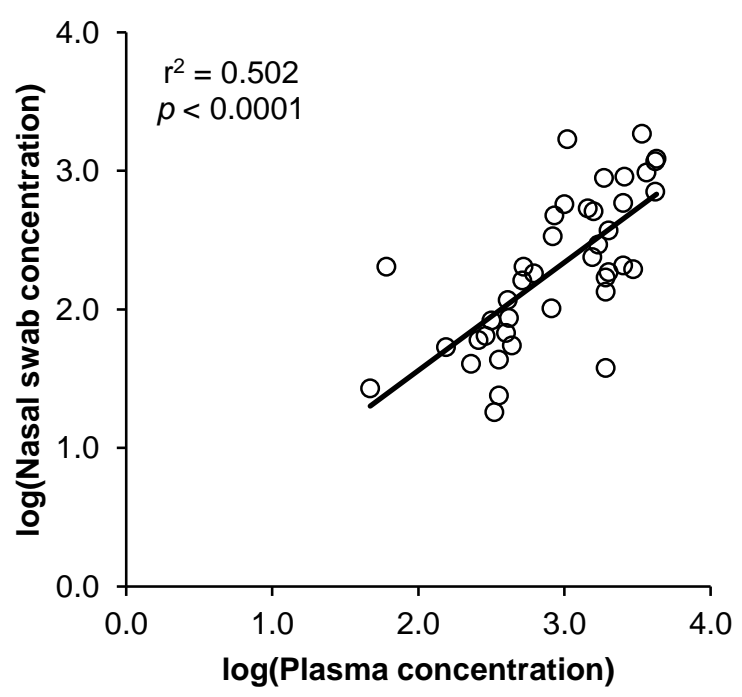

(C)

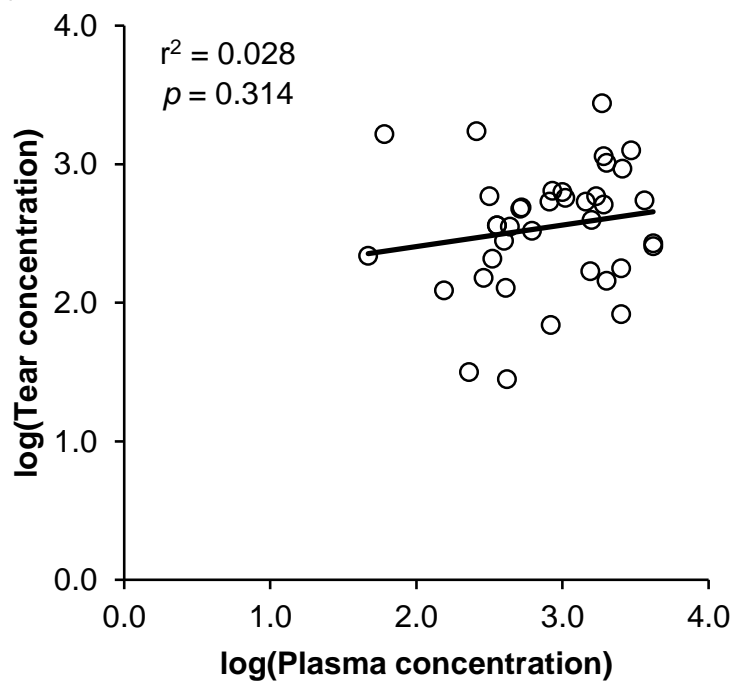

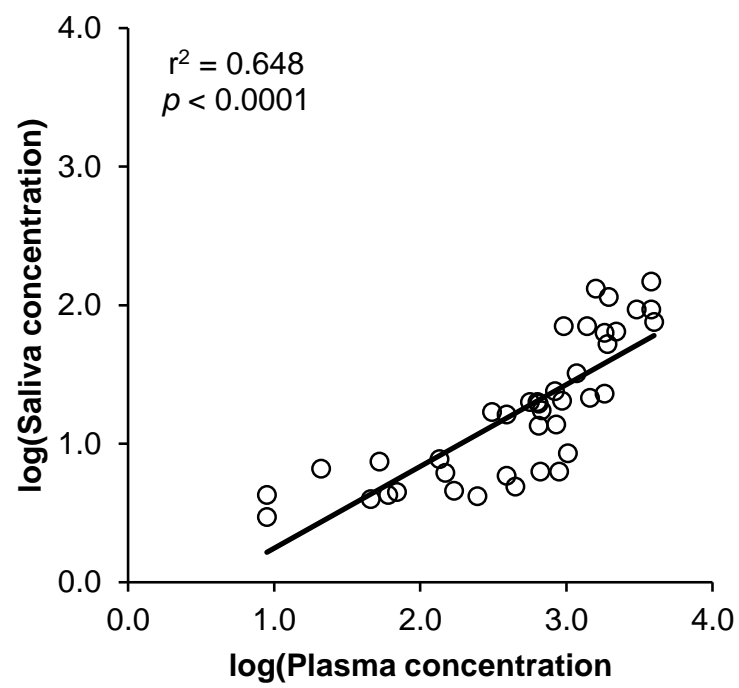
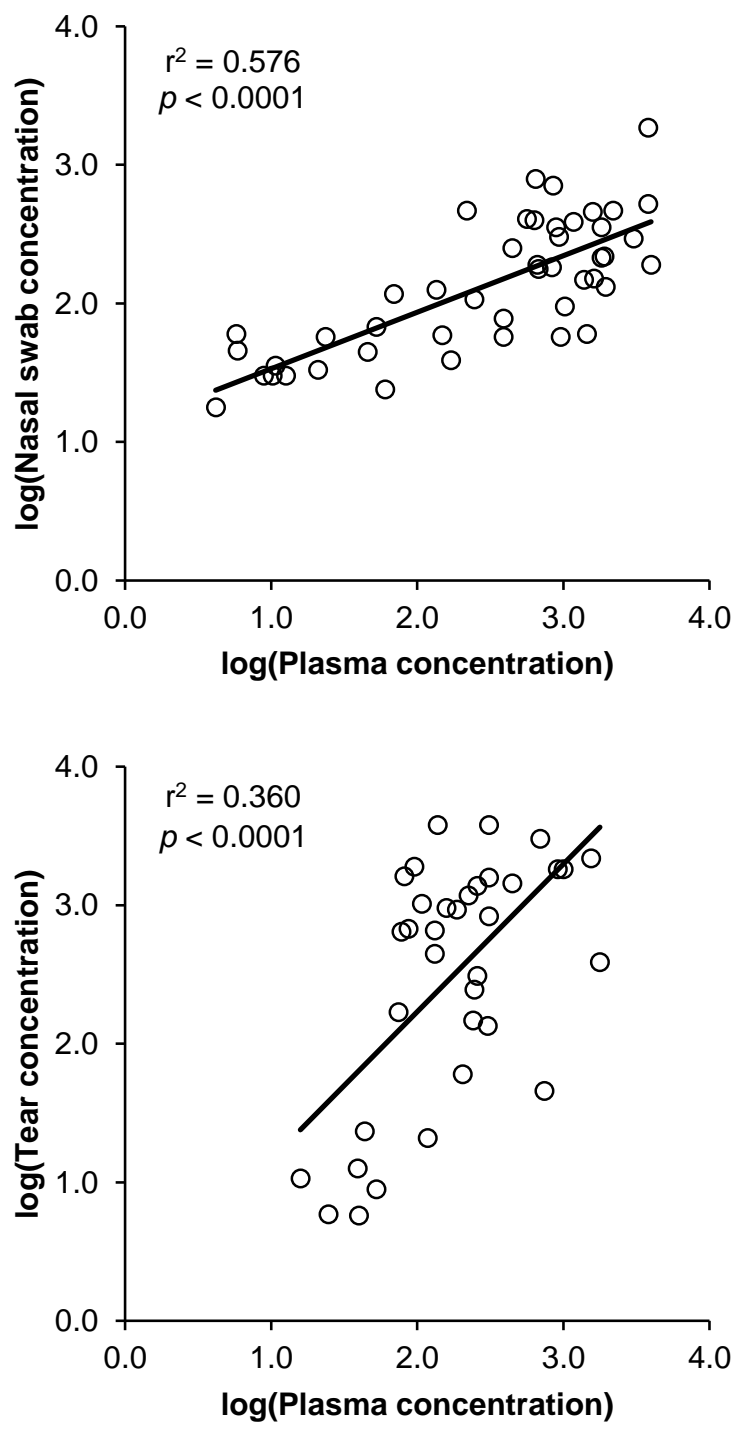